\title{
Delayed Neurological Recovery After Ultrasound-Guided Brachial Plexus Block: A Case Report [Response to Letter]
}

This article was published in the following Dove Press journal: Local and Regional Anesthesia

\author{
Ninadini Shrestha' \\ Bipin Karki (iD) ${ }^{2}$ \\ Megha Koirala' \\ Santosh Acharya ${ }^{3}$ \\ Pramesh Sunder Shrestha' \\ Subhash Prasad Acharya (ID) \\ 'Department of Anaesthesia, Maharajgunj \\ Medical Campus, Institute of Medicine, \\ Maharajgunj, Kathmandu, Nepal; \\ ${ }^{2}$ Department of Critical Care Medicine, \\ Om Hospital and Research Center Pvt. \\ Ltd, Chabahil, Kathmandu, Nepal; \\ ${ }^{3}$ Department of Critical Care Medicine, \\ Hospital for Advanced Medicine and \\ Surgery, Dhumbarahi, Kathmandu, Nepal
}

Correspondence: Bipin Karki

Om Hospital and Research Center Pvt.

Ltd., GPO I3494, Chabahil, Kathmandu,

Nepal

Tel +977-9841701269

Fax +977-I-4466I28

Email karki_bipin@yahoo.com

\section{Dear editor}

We would like to thank Dr. Mangla and Dr. Yarmush for their interest in our case report. We appreciate their effort and knowledge with which they have raised their concerns regarding the case report.

Firstly, the patient had an American Society of Anesthesiologists, Physical Status (ASA PS) class I status as mentioned in the case description. Thus, it goes without mentioning that the patient was a non-smoking healthy individual with no known co-morbidities, no alcohol use and a body mass index within normal ranges. ${ }^{1}$ To add, he had undergone a pre-anaesthetic assessment before surgery with investigations as per the institutional practice which included a complete blood count (including a platelet count, prothrombin time and international normalized ratio for cases planned under regional anaesthesia), serum sodium, potassium, urea and creatinine levels. All of these parameters were within normal ranges. For the surgery, the patient was put in right lateral position with a padded support below the left elbow with the shoulder abducted at 90 degrees for the entire duration of the surgery which as mentioned in the report was 130 minutes. There were no episodes of hypotension or hypoxemia in the pre-, intra- or the post-operative periods. Hence, no pre- or intra- operative risk factors for neuropathy was present in the patient. ${ }^{2}$ As they have mentioned in their letter, the tourniquet can cause a reversible block distal to it. Also, a more appropriate method of determining the adequate pressure would have been by measuring the limb occlusion pressure rather than using $250 \mathrm{~mm}$ of Mercury pressure. ${ }^{3}$ However, we think that it is unlikely for the tourniquet to have caused the delayed recovery in this case since the block had persisted even above the site of its application (C5 to T1 dermatomes) till week three. ${ }^{4}$

Secondly, as pointed out and as we have mentioned in the discussion of the case report, an early nerve conduction study (before three to four weeks) may be normal. ${ }^{5}$ By week three after the administration of the block, the patient had started to develop paresthesia. He was advised for a repeat nerve conduction test by the neurologist but he declined to it. He had made a valid point that the clinical management would not change with the results of the test and had opted to wait for a few more weeks. By the sixth week, the patient had recovered sensation of the entire upper limb with partial recovery of the motor functions. 
Thirdly, brachial plexus injuries can be easily found in the literature following peripheral nerve blocks. ${ }^{2,6-8}$ They are one of the common adverse events in anesthesia but are often limited to either individual nerves or some part of the brachial plexus trunk. ${ }^{9}$ We could not agree more with the statement that the conclusion we came to was not based on strong evidence. This conclusion however was made after ruling out all other causes. The current understanding of the in-vivo effects of local anesthetic agents and adjuvants is very limited since most research regarding the inherent toxicity of these drugs are based on in vitro models. ${ }^{10}$

Thank you for showing interest in the case report and for the opportunity to respond to the letter.

\section{Disclosure}

The authors report no conflicts of interest in this communication.

\section{References}

1. American Society of Anesthesiologists. ASA physical status classification system; 2019. Available from: http://www.asahq/org.
2. Brull R, McCartney CJL, Chan VWS, El-Beheiry H. Neurological complications after regional anesthesia: contemporary estimates of risk. Anesth Analg. 2007;104(4):965-974. doi:10.1213/01.ane.0000 258740.17193.ec

3. Kumar K, Railton C, Tawfic Q. Tourniquet application during anesthesia: "What we need to know?". J Anaesthesiol Clin Pharmacol. 2016;32(4):424-430. doi:10.4103/0970-9185.168174

4. Carrera A, Lopez AM, Sala-Blanch X, Kapur E, Hasanbegovic I, Hadzic A Functional regional anesthesia anatomy. Available from: http://www.nysora.com.

5. Robinson LR. Traumatic injury to peripheral nerves. Muscle Nerve. 2000;23(6):863-873. doi:10.1002/(SICI)1097-4598(200006)23:6<86 $3::$ AID-MUS4 $>3.0 . \mathrm{CO} ; 2-0$

6. Davis JJ, Swenson JD, Greis PE, Burks RT, Tashjian RZ. Interscalene block for postoperative analgesia using only ultrasound guidance: the outcome in 200 patients. J Clin Anesth. 2009;21(4):272-277. doi:10. 1016/j.jclinane.2008.08.022

7. Steinfeldt T, Nimphius W, Werner T, et al. Nerve injury by needle nerve perforation in regional anaesthesia: does size matter? $\mathrm{Br}$ J Anaesth. 2010;104(2):245-253. doi:10.1093/bja/aep366

8. Hewson DW, Bedforth NM, Hardman JG. Peripheral nerve injury arising in anaesthesia practice. Anaesthesia. 2018;73:51-60. doi:10. 1111/anae. 14140

9. Barrington M, Brull R, Reina M, Hadzic A. Complications and prevention of neurologic injury with peripheral nerve blocks. Available from: http://www.nysora.com.

10. Knight JB, Schott NJ, Kentor ML, Williams BA. Neurotoxicity questions regarding common peripheral nerve block adjuvants in combination with local anesthetics. Curr Opin Anaesthesiol. 2015; 28(5):598-604. doi:10.1097/ACO.0000000000000222

\section{Publish your work in this journal}

Local and Regional Anesthesia is an international, peer-reviewed, open access journal publishing on the development, pharmacology, delivery and targeting and clinical use of local and regional anesthetics and analgesics. The journal welcomes submitted papers covering original research, basic science, clinical studies, reviews \& evaluations, guidelines, expert opinion and commentary, case reports and extended reports. The manuscript management system is completely online and includes a very quick and fair peer-review system, which is all easy to use. Visit http://www.dovepress.com/testimonials. php to read real quotes from published authors. 